\title{
Mal De Ojo and Other Poems
}

Alba Alonso Palombi, University of Warwick

\section{Abstract}

Female sexuality makes people uncomfortable, and, from this fact, rises the Madonna and whore dichotomy, as it allows for the division and neat categorisation of chaste and promiscuous women that keeps female sexuality in check. In both the Madonna and the whore, the sexual facet is outside of the woman's control, and both are objects of desire for the heterosexual male - very much like the femme fatale. I have here three poems that reflect on female figures and how they have been viewed through their sexual acts, and their vilification or idolisation.

\section{Mal de Ojo}

Spoon out my eyes with your fingers,

clearly I loved you too much.

The good doesn't last and the other lingers,

I miss your winged touch.

It was my green that cursed us

clearly I loved you too much.

The lonely's ok, it's the silence that cuts.

I throw sand in my face, but color doesn't change

it was my green that cursed us.

They call me a witch and arrange

my pyre, and I, soon to be bones

throw sand in my face, but color doesn't change.

I see what you don't want to own

and you, scared, blame it on a curse and prepare

my pyre. I, soon to be bones,

kneel, wail, pull out my hair.

Spoon out my eyes with your fingers! 
You, scared, blame it on a curse. I prepare.

The good doesn't last and the other lingers.

\section{Merlin Killed By Gold Digger}

The wizard lies caught

by roots and branches and leaves.

He fell prey to her, the child lied with him and meanwhile she lied to him and stole his secrets, or so the tale goes.

I have been to the forest where he was enthralled, and the grass whispered that he asked for his prison of bark, dark, and moss.

The worms know the truth, of the gifted, not stolen, of the girl who took the heavy burden off his frail chiselled shoulders.

Of love turned treason by those who could not, by those jealous of her worth blinded by her locks of auburn. By sex and what she could not. By sex and the witches' blood. And the witches' blood and what she could not. By sex of auburn. By sex blinded by her locks. By those jealous of her worth, by those who could not, of love turned treason.

Off his frail chiselled shoulders the heavy burden. The girl who took it, 
of the gifted, not stolen.

The worms know the truth, of bark, dark, and moss.

That he asked for his prison, and the grass whispered where he was enthralled. I have been to the forest, or so the tale goes, stolen his secrets.

And meanwhile she lied to him, the child lied with him.

He fell prey to her, by roots, and branches and leaves.

The wizard lies caught.

\section{Mandorla}

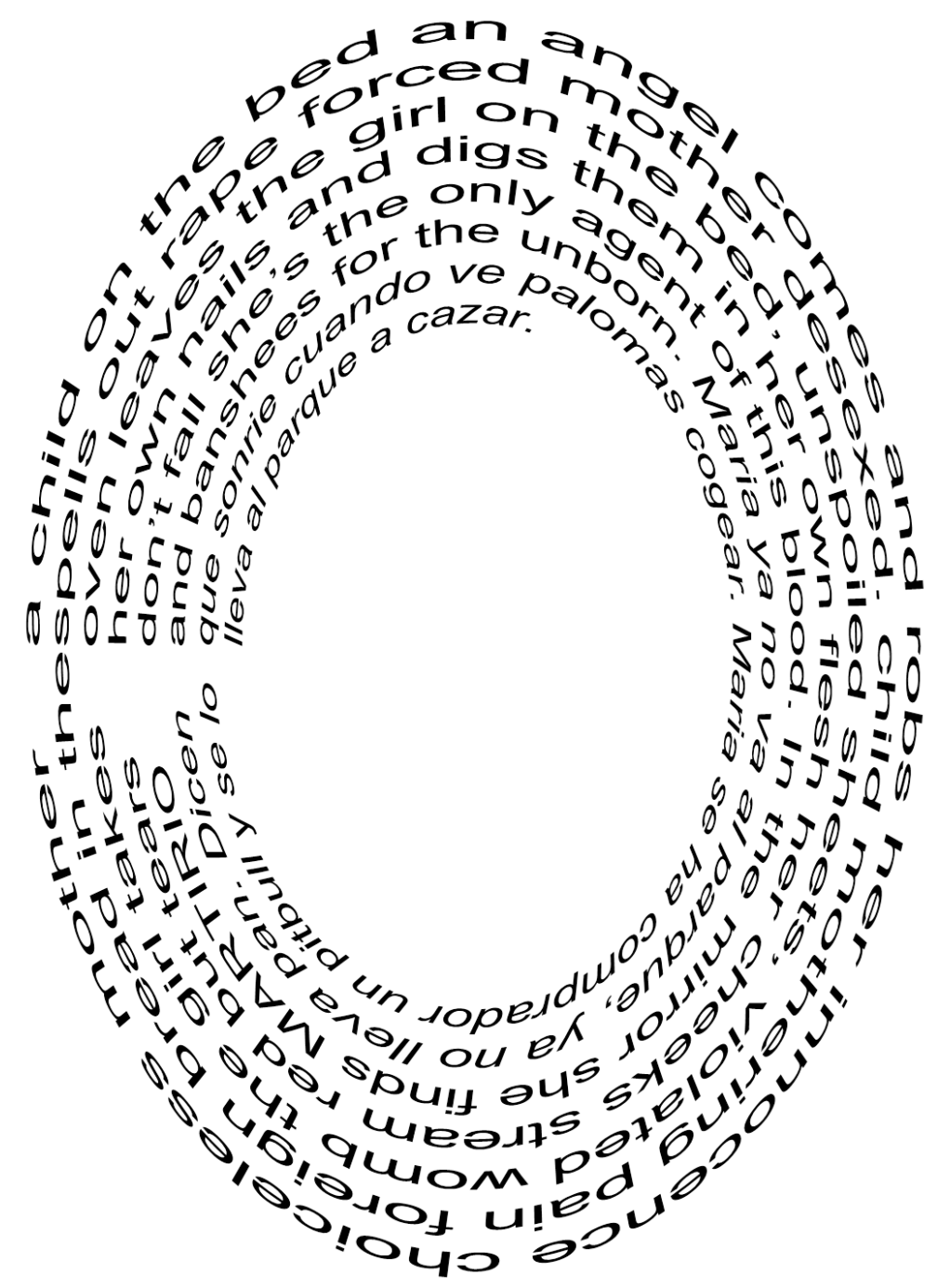




\section{Transcript}

a child on the bed

angel comes and robs her innocence

choiceless mother spells out rape

forced mother desexed. child mothering pain

foreign bread in the oven leaves the girl on the bed, unspoiled sheets, violated womb

the girl takes her own nails and digs them in her own flesh

her cheeks stream red but tears don't fall

she's the only agent of this blood.

In the mirror she finds Martirio and banshees for the unborn.

María ya no va al parque, ya no lleva pan. Dicen que sonríe cuando ve palomas cojear.

María se ha comprado un pitbull y se lo lleva al parque a cazar.

To cite this paper please use the following details: Alonso Palombi, A. (2022), 'Mal De Ojo and Other Poems', Reinvention: an International Journal of Undergraduate Research, Special Issue I Reeling and Writhing: Intertextuality and Myth, https://reinventionjournal.org/article/view/982. Date accessed [insert date]. If you cite this article or use it in any teaching or other related activities please let us know by e-mailing us at Reinventionjournal@warwick.ac.uk. 